\title{
Sprawozdanie z warsztatów duszpasterskich 14-15 II 2012 roku
}

Głoszenie Ewangelii jest misją Kościoła. W dobie współczesnych przemian ideologicznych, koniecznym staje się wypracowanie nowych form przepowiadania, nieodzowną jest refleksja nad „nową ewangelizacją". W celu ich wypracowania Międzywydziałowa Katedra Teologii Katolickiej Uniwersytetu w Białymstoku w dniach 14-15.02.2012 roku zorganizowała dla księży warsztaty duszpasterskie pod hasłem Nowa ewangelizacja, które się odbyły w Archidiecezjalnym Wyższym Seminarium Duchownym w Białymstoku. Zgromadziły one ponad dwustu pięćdziesięciu duchownych. Gościem warsztatów był bp dr Edward Dajczak, ordynariusz diecezji koszalińsko-kołobrzeskiej. Całość prowadził ks. prof. UwB dr hab. Adam Skreczko, wikariusz biskupi ds. stałej formacji kapłanów. Warsztaty składały się z konferencji, pracy w grupach konwersatoryjnych.

W swojej prelekcji bp Dajczak najwięcej uwagi poświęcił duszpasterstwu młodzieży. Odwołując się do badań naukowych z zakresu komunikacji społecznej przeprowadzonych przez Opus Dei, przedstawił diagnozę młodego pokolenia, które posługuje się nowym kodem komunikacyjnym, wirtualnym przeżywaniem, spowodowanym spędzaniem czasu w wirtualnej rzeczywistości internetu. Rys ów sprecyzował wokół czterech cech: 1) człowiek nie jest w stanie organizować informacji, tylko reaguje na bodźce, co związane jest $\mathrm{z}$ wirtualizacją życia, zmierzającą do szukania emocji, wrażeń, a nie wiedzy; 2) młodzi nie są złaknieni informacji religijnych, lecz pragną osobowego doświadczenia Boga; 3) kryzys autorytetu obiektywnego łączy się z potrzebą autorytetu osoby - młodzież przede wszystkim trzeba kochać miłością wymagającą, jedynie tak można ją doprowadzić do wiary; 4) wobec moralnego kryzysu tożsamości młodego człowieka istotnym wezwaniem jawi się przeżycie głębi w wierze. Prelegent wskazał na problemy, z którymi musi zmierzyć się ewangelizacja w dzisiejszym świecie. Postępujący laicyzm, indyferentyzm moralny, natłok docierających informacji oraz 
spadek, a często zanik życia religijnego w rodzinach, to tylko niektóre z trudności, na które obecnie napotykają duszpasterze.

Na podstawie powyższych spostrzeżeń bp Dajczak określił nową ewangelizację jako „wejście w rzeczywistość współczesnego człowieka, który w sposób przedmiotowy i indywidualny odbiera świat". Przeto ewangelizacja nabiera rys personalistycznych: nie jest frontową metodą przekazywania nauki religijnej, lecz wychodzi naprzeciw potrzebom ludzkim i przekazuje Ewangelię, dostosowując jej przekaz do podmiotowych zdolności percepcyjnych człowieka. Prelegent nadto podkreślił znaczenie elementu przeżyciowego w ewangelizacji, gdyż w dzisiejszym świecie nie wystarczy przekazywać jedynie samej wiedzy religijnej i formuł wiary. „Należy wypracować sposób przekazywania wiary, a nie informacji. Pierwszą twarzą Ewangelii nie może być wiedza. Młodzież jest zainteresowana kluczem do życia. Trzeba zatem wyrabiać motywację sakramentalną poprzez dialog, który kształtuje wiarę. Bliskie, bezpośrednie i emocjonalne doznania są bliższe młodemu pokoleniu niż logiczne myślenie. Problemem, a jednocześnie wyzwaniem dla duszpasterzy jest doprowadzenie młodych do spotkania Boga, dotarcie do ich serc. $Z$ racji zaś silnego utożsamiania się z wartościami grup rówieśniczych, sposobem ewangelizacji może stać się tworzenie wspólnot przyjaźni" - mówił Ordynariusz koszalińsko - kołobrzeski.

Prelegent wielokrotnie podkreślał dostrzegalne u młodych poszukiwanie wartości i pragnienie Boga, które „niejednokrotnie roztrzaskują się o skałę jurysdykcyjnego Kościoła, w którym nikt - ani księża, ani katecheci, ani rodzice nie mają czasu i cierpliwości do bycia z młodzieżą". Zachęcał uczestników warsztatów do podchodzenia z miłością do młodego człowieka, niejednokrotnie rozdartego między ideałami a płytkością życia społecznego, które go otacza. Stąd rodzi się jego bunt. Wobec zagubienia aksjologicznego młodego pokolenia, ewangelizacja powinna pomóc wierzyć, doprowadzić do osobowego spotkania z przychodzącym Jezusem Chrystusem.

Po wysłuchaniu konferencji, duchowni w trzech grupach konwersatoryjnych pracowali na temat ewangelizacji dzieci, młodzieży i osób dorosłych. Na zakończenie prac przewodniczący grup zaprezentowali na forum wypracowane wnioski.

Ks. mgr lic. Jerzy Sęczek, którego grupa rozważała nad ewangelizacją dzieci, przedstawił rozwiązanie tegoż zagadnienia w ewangelizowaniu rodziców przez dzieci. W tym celu powinno wykorzystywać się zastane formy: mszę świętą z udziałem dzieci. Wyakcentował postulat otwartości: celebrans winien katechizować dzieci. Podkreślił nadto 
problem egzekwowania wiedzy i praktyk religijnych na katechezach parafialnych. W tej materii trzeba wypracować nowe formy mobilizacji dzieci, by Kościół nie kojarzył im się tylko z zaliczaniem modlitw.

Z kolei ks. dr Jarosław Grzegorczyk, którego grupa skupiła się wokół zagadnienia ewangelizacji młodzieży, zarysował punkty zapalne przygotowań do bierzmowania, a mianowicie kwestię kontroli religijności młodych w postaci wpisów do książeczek ze mszy świętych, nabożeństw itp. Zwrócił uwagę na potrzebę kształtowania jakości kapłana jako duszpasterza wokół takich cech jak gorliwość i zaangażowanie. Panaceum na dobre przygotowanie młodzieży ma stać się podmiotowe podejście do młodych, tj. bycie duszpasterza z nimi.

Następnie wyniki pracy grupy wokół tematu ewangelizacji dorosłych zaprezentował ks. dr Zbigniew Snarski. Podkreślił konieczność dobrego przeżycia liturgii z aktywnym udziałem świeckich, które może być skuteczną formą budzenia wiary. Podkreślił punkt wyjścia nowej ewangelizacji - pedagogizację rodzin.

Podsumowując zaproponowane przez uczestników warsztatów rozwiązania duszpasterskie, bp Dajczak zwrócił uwagę na fundament ewangelizacji, którym winna być miłość do człowieka, poszukującego Prawdy, nieraz buntującego się. „Ewangelizator musi być przyjacielem ludzi - mówił - gdyż młodzi nie chcą widzieć Kościoła jako jeszcze jednej instytucji, lecz jako rodzinę, wspólnotę miłości, w której mogą kształtować swoją osobowość".

W słowie kończącym warsztaty ks. abp prof. dr hab. Edward Ozorowski wyakcentował konieczność wypracowania nowych form ewangelizacji: „Ewangelia jest ciągle ta sama, ale inni są ludzie dziś niż byli wczoraj. Zmieniają się, mają inne problemy i posługują się innymi środkami komunikacji. Jeśli mamy być skutecznymi ewangelizatorami, musimy inspirować młodych ludzi do stawiania trudnych pytań".

Podczas warsztatów bp Dajczak spotkał się również z alumnami białostockiego seminarium. Odwołując się do swojego kapłaństwa i doświadczenia pracy duszpasterskiej, przekonywał, że ludzie potrzebują dziś kapłanów całkowicie oddanych Bogu, którzy jedynie w ten sposób mogą stać się prawdziwymi świadkami i przewodnikami w drodze ku Chrystusowi.

Warsztaty dla kapłanów Archidiecezji Białostockiej organizowane są cyklicznie przez Międzywydziałową Katedrę Teologii Katolickiej Uniwersytetu w Białymstoku. Ich celem jest zdobycie wiedzy, poszerzenie praktycznych umiejętności oraz wypracowanie nowych i skutecznych metod działania w kontekście współczesnych wyzwań duszpasterskich. 